総説 第 $29 \cdot 30$ 回教育研修会 (2008 年口腔四学会合同研修会) 「デンタルインプラントの基本とその応用」

\title{
インプラント治療における基本手技
}

\author{
渡邊文彦
}

\section{Basic technique on implant treatment}

\author{
WATANABE Fumihiko
}

\begin{abstract}
Implant treatments have been applied clinically over 40 years since osseointegrated implant rehabilitation had been introduced in early 1960's. For these years, many research papers are reported in Europe, America and Asian countries on basic research and clinical application. Now, Implant treatments covered from single tooth missing to total edentulous and they are restored esthetically and functionally and naturally. In background, there are advancement of treatment techniques, improvement of implant system and higher level of Quality of Life of patients. Concretely, they are extension of implant indications and maintenance of circumference surrounding implant by hard and soft tissue management. On implant success, implant team approach consisting of dentist, dental hygienist, dental technician and patient's family for patients sharing of treatment goal are extremely important. Restoration driven is one of the treatement method decided by final restoration which are planned with patient's desire, local condition, general condition. Number of implants, implant size, implant position and necessity of hard tissue management are decided.

Nowadays, even though patients demand immediate loading by reason of shortening of treatment period, the treatment method do not recognized routinely except over denture for mandibulor total edentulous. For the success of implant success, patients conditions including local, general, psychological conditions, plaque control and patient's corporation for implant treatment are not only important but also treatment ability and technique of dental team.
\end{abstract}

Key words: tooth for tooth implant（1㐘 1 本のインプラント), team approach（チームアプローチ), immediate loading (即時荷重), implant over denture（インプラントオーバーデンチャー）

\section{緒}

\section{言}

\section{今日のインプラント治療に求められるもの}

Branemark らによりチタンと骨とのオッセオインテグレ ーションが定義され，オッセオインテグレーテッドインプ ラントが臨床応用されてからすでに 40 年が経過している. この間，欧米，またアジアを中心に骨内インプラントに関 する多くの基礎研究, 臨床評価, 報告されてきた. その応 用は現在, 審美的機能的回復, 残存㐘への侵襲の回避, 長 期間の予後等の点から, 欠損修復に扎ける, 有力な選択肢 となっている. Branemark らによりオッセオインテグレー テッドインプラントの臨床応用がスタートした時点の適応

日本柬科大学新潟生命菌学部菌科補綴学第 2 講座

Department of Crown \& Bridge Prosthodontics, School of Life

Dentistry at Niigata, The Nippon Dental University
は下顎の高度に吸収した無㐘顎で, 機能を重視したインプ ラント治療であった ${ }^{1)}$. 現在はその適応は拡大進歩し, 喪 失した㐘の代わりとしての機能はもちろんのこと天然㐘と 区別困難な審美機能的回復が行われている，この背景には インプラント治療を行うにあたってのハードウエアーつま りインプラント材料の改良とソフトウエアーつまりインプ ラント治療技術またこれに関係する口腔外科修復技術の進 歩がある（図 1).インプラント材料においてはインプラン トの形状, 表面性状, アバットメントとインプラント体と の連結機構, インプラント補綴材料, インプラント外科器 材の改良がある.また治療技術の進歩では治療に対する考 え方，つまり骨の存在する部位へのインプラントする治療 から最終修復を見据えたインプラント治療への考え方への 変遷 ${ }^{2)}$ や診断, 骨移植, 軟組織移植の術式の応用, 細かく は歯肉粘膜の剥離, 縫合法などがある. 


\begin{tabular}{|lc|}
\hline \multicolumn{2}{|c|}{ Implant Rehabilitation } \\
\multicolumn{2}{|c|}{ Improvements } \\
Hardware & Software \\
Implant design & Treatment concepts \\
Implant surface & Diagnostics \\
Implant abutment connection & Surgical techniques \\
Components & Flap design \\
Armamentarium & Hard tissue management \\
& Soft tìssue management \\
& Suturing technique \\
\hline
\end{tabular}

図 1 インプラント材料とインプラント治療の变遷

具体的には骨移植，スプリットクレスト，上顎洞底挙上 術，仮骨延長，下顎骨移動術等のハードテッシュ，歯肉粘 膜移植, 結合組織移植, 前庭拡張術等のソフトテッシュマ ネージメントの導入はインプラント治療の適応症を大きく 拡大し, 番美的な回復を可能にした。さらに上部構造の適 合，製作のし易さ，審美性から 1 㐘欠損に対して 1 本のイ ンプラントする治療法が推奨されてきた. またインプラン トの予後に打いても治療技術の向上と材料の改良により長 期間の高い生存率, 成功が報告されている. 現在多くのイ ンプラント治療に対する評価がなされているが，患者さん に対してインプラント治療で何年まで持てばよいのかのア ンケート調査では 10 年で $9 \%, 15$ 年で $19 \%, 20$ 年で $72 \%$ とできるだけ長く持って欲しいとの結果が報告され ている ${ }^{3)}$. 今日求められるまた受け入れられるインプラン 卜治療はこのような審美と長期間の良好な機能をもつもの でなければならない。

\section{インプラント治療にとって必要なもの}

\section{1.インプラントにおけるチームアプローチ}

インプラント治療には比較的簡単なケースから適応症拡 大を含む難症例まで，さらに全身的疾患を有する患者がい る.インプラント治療は単にインプラント埋入することで はなく，インプラントを支台として審美的機能的回復がな され，長期間の予後をもつことが求められている.このこ とから各専門分野の知識, 技術が必要となる。一人の柬科 医師が埋入，修復まで行い，これに歯科技工士，歯科衛生 士がチームを組み治療にあたる, 所謂チームアプローチが 大切である. 場合により口腔外科医，茵科麻酔医，歯周治 療医とのチーム編成, 内科医, 整形外科医とのチーム編成 が必要である.チームアプローチには患者にとっての同じ

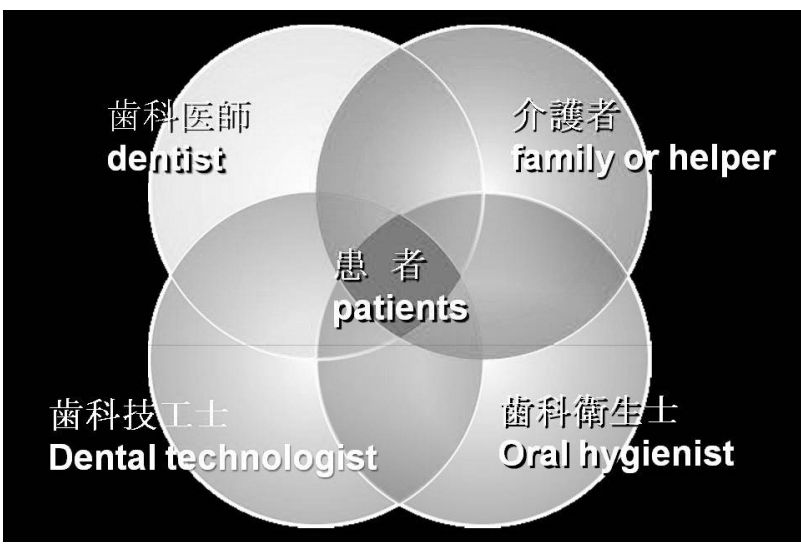

図 2 インプラント治療における連携

ゴールを共有することが必須である.インプラント治療が 長期にわたって予後が期待されてくるとインプラントより も患者の全身状態が悪くなり，ブラッシングが困難となる 場合があり，このような症例では家族による協力が必要と なる。つまりインプラント治療は述べるまでもなく患者を 中心に歯科医師，歯科技工士，歯科衛生士，家族が連携協 力をとり治療にあたることが将来のインプラント治療に重 要な鍵となる（図 2).

\section{2. 最終ゴールからのインプラント治療}

インプラント治療にとってのゴールはオッセオインテグ レーションの獲得ではなく，埋入されたインプラントを支 台とした審美機能回復にある. 過去, インプラント周囲の 局所的な骨の状態からインプラント治療の適応, 埋入位置, 部位，インプラントサイズを選択していた。しかし現在は 患者が求める最終修復がどのようなものであるのかを十分 理解し, 患者の全身状態, 局所状態を十分把握したうえで, 治療計画を立案しなければならない,つまり,インプラン 卜埋入手術はこの最終ゴールにあったものでなければなら ない. 1980 年代後半から GTR や骨移植の術式が応用され るようになり, インプラント周囲の環境も整備され，その 上で最良のインプラント埋入手術が行われるようになって きた。具体的には骨移植などのハードテッシュマネージメ ントやソフトテッシュマネージメントにより, 適応症の拡 大, 審美性の回復, 大直径のまた長いサイズのインプラン トが可能である. 抜㐘即時インプラント埋入時選択するイ ンプラント直径は本来あった柬の近遠心歯頸部径（セメン トエナメル境 $3 \mathrm{~mm}$ 根尖側の径) が適切である. 通常のイ ンプラント埋入に打いても本来の菊頸部径にあったインプ ラントでの回復は蒾頸部のクラウンの立ち上がりの部分が 自然であり，また清掃性もよいと考えられる（図3). 市販 


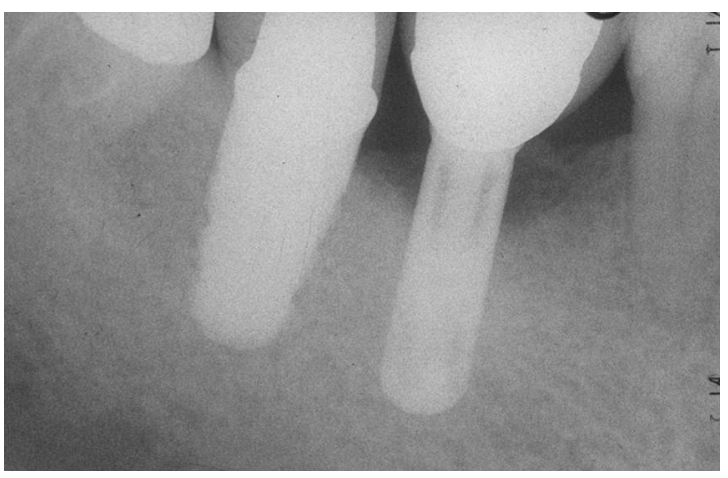

図 3 インプラント直径と上部構造 大臼藏部に用いられた直径 $4.0 \mathrm{~mm}$ と $6.5 \mathrm{~mm}$ のインプラント体. 上部構造体とインプラント 連結部に注目.

のインプラントはほとんどがシリンダー型, ルートホーム であり，その断面は円形である. 天然柬をみると菊種によ り形状は異なる。このような点から通常は唇煩舌径の骨幅 でインプラント直径を選択しているが, 下顎前茵, 小臼柬 では近遠心径が唇煩舌径よりも小さく，隣接する茵根，イ ンプラント体を考慮すると, 近遠心径を参考とすべきであ る.

\section{3. インプラント埋入位置と方向}

インプラントの埋入位置と方向は上部構造や, アバット メントスクリュー, インプラント周囲骨に対して, 力学的, 生体力学的に有用な意味をもつ. インプラント体の埋入位 置の異常は不適切な上部構造の形態を生じさせる，時とし てインプラント体の傾斜は上部構造体製作に困難を生む. さらにインプラント上部構造の破折，アバットメントスク リューの緩みや破折，インプラント周囲骨の破折を生じさ せる ${ }^{4)}$. 特に下顎臼柬部では舌側に 105 度傾斜しているた め, 煩舌側骨の中央に埋入すると舌側に傾斜埋入される (図 4) ${ }^{7)}$. 手術時手術台を水平にすると咬合平面が確認し づらくなる. また有空巾を覆うとさらに咬合平面は確認し づらい. 埋入方向はガイドホールを形成した時点で，対合 柬, 隣接柬, 咬合平面との関係を確認することが大切であ る.

\section{4 . インプラント周囲状態の環境整備}

インプラント埋入に際しては術前，十分に骨幅，骨量， 付着㐘肉, 粘膜の厚み等を十分に検討しておくことが必要 であり, 最終ゴールがどのようになるのか術前予測するこ とが必要である，もしインプラント埋入手術するに十分な 骨がないのであれば，リスク，費用，予知性を説明した上

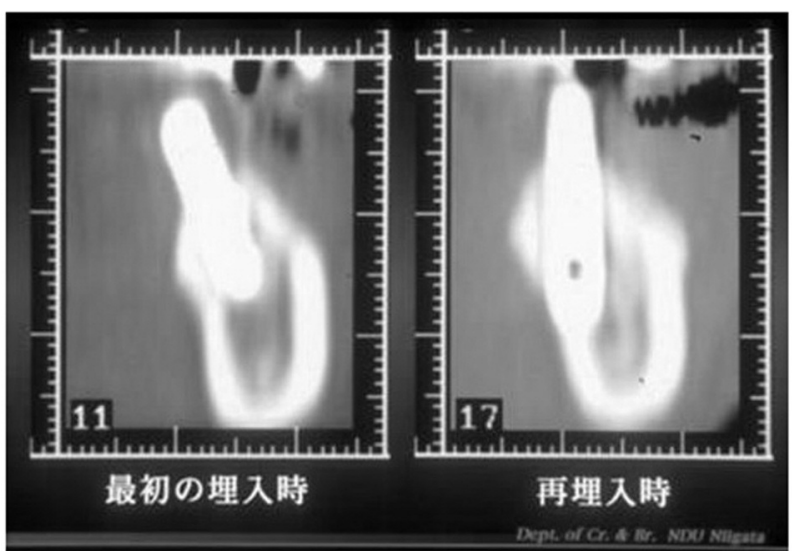

図 4 下顎大白柬部へのインプラントの埋入

で，患者の同意が得ら得るのであればハードテッシュマネ ージメント, あるいは付着歯肉幅がない場合には埋入時, 二次手術でこれらの処置を計画する.ここでも患者さんの 特に審美的な要求がどのようなものであるかを十分理解 し, 治療計画を立て, 実行する.オッセオインテグレーテ ッドインプラントが臨床応用された初期段階のインプラン 卜治療とは大きく異なっている. 今日求められるインプラ ントはオッセオインテグレーションを基にしている点では 変わらないが, 治療術式はより高度となり, 天然柬と類似 した自然な審美, 機能, かつ長期間の予後をもつことが求 められている.このためには前記した骨移植, GTR, スプ リットクレスト, 上顎洞底挙上術, 仮骨延長, 結合組織移 植, 前庭拡張術, 柬肉粘膜移植が必要である.

\section{5 . インプラント治療の生存率}

日本柬科大学新潟生命柬学部と, 新潟県三条市榎本蒾科 医院の 2 施設で 1987 年から 2001 年までの 13 年間に行わ れたインプラント体内部に可動性機構 (Inter Mobile Element, Inter Mobile Connector) を有する IMZオッセオ インテグレーテッドインプラント 972 本, 271 人を対象に 予後評価報告した ${ }^{5)}$. その結果, リコール率は $93.7 \%$ で, 両施設での累積生存率は 5 年目で $96.3 \%, 10$ 年目で $92.6 \%, 13$ 年目で $89.9 \%$ であった. またインプラントと天 然㐘との連結については日本㐘科大学新潟生命茵学部で $12.1 \%$, 榎本茵科医院で $6.8 \%$ に連接蒾の破折が認められ た（図 5)。その何れも失活歯であった。この原因は連結し たインプラントの被圧変異量と失活㐘の被圧変異量が異な りその応力が天然柬の柬頸部に生じクラウンを装着してい るセメントに伝達させ, セメントの溶出を生じさせ, 支台 築造体と根管象牙質との間の弾性率の違いにより, 支台築 


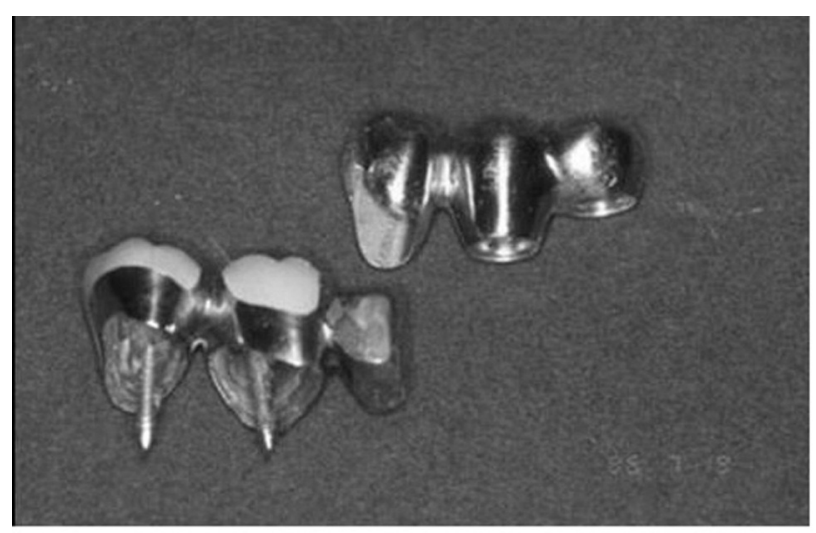

連結柬が失活㐘の場合

連結ブリッジの応力集中が天然柬の柬頸部に集中
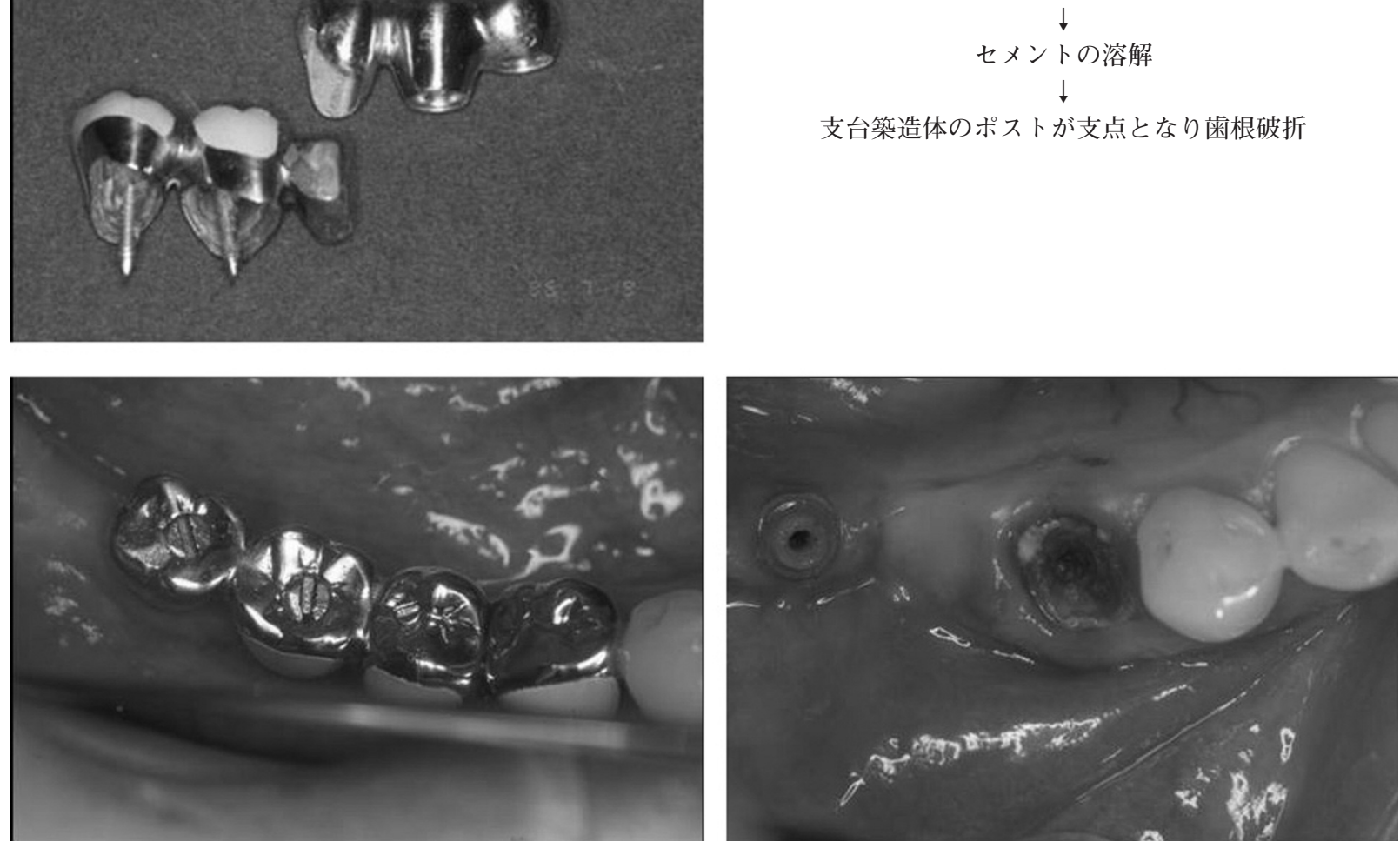

図 5 インプラントと天然柬の連結による破折

造体と根管との間のセメントが溶出し, 支台築造体がたわ むことにより根管の縦破折を起こしたものと推察される. しかし, 連結した有髄柬の破折は認められなかった。

\section{6 .スクリュー固定式ブリッジ}

多くのオッセオインテグレーテッドインプラントは清掃 性, 咬合調整のし易さからスクリュー固定式のブッリジが また, IMZ インプラントはインプラント体内部の可動性機 構 IMC や IME を定期的に交換するためスクリュー可撤式 上部構造が応用されてきた。これらのスクリュー固定式ブ リッジはインプラント体あるいはインプラント体に連結し たブリッジアバットメント上に上部構造を装着し，スクリ ューで固定する.スクリュー固定は適合の如何により装着 可能であるが，不適合のブリッジを装着した場にはスクリ ュー, ブリッジ，インプラント体への応力の集中を生む. その結果時としてスクリューの破折やゆるみ, ブリッジの 破折，オッセオインテグレーションの消失を生じる危険性 が有る.スクリュー固定式のブリッジの製作法は通常 4 つ の方法がとられる. ワンピースキャスト, 鑞着法, ワンピ 一スキャスト後切断しろう着, そしてパッシブフィット法 である. 著者らはこれらの製作方法と適合精度を調べるた
め, ウレタンブロックに 3 本の IMZ インプラントを埋入 し，インプラント周囲に 6 つ歪みゲージを貼り，スクリ ユ一固定時の応力の発生を測定する基礎的な研究を行っ た ${ }^{6)}$. その結果，ろう着とパッシブフィット法で製作した ブリッジはブリッジをスクリュー固定時発生する応力が小 さかったのに対し，ワンピースキャスト法，ワンピースキ ヤスト後切断しろう着する方法では大きな応力がインプラ ント周囲に生じた (図 6). このことより，スクリュー固定 法はロングスパンのブリッジでは応力が生じやすいことが 明らかとなった。このような技工操作，上部構造の精度， 審美の点からインプラント修復は 1 本の欠損に対して 1 本 の修復で，セメント固定による修復が良いのではないかと の結論に達した。IMZインプラントの開発者の Axel Kirsch らは 1 㐘 1 本で使用しクラウンをインプラント上の アバットメントにセメント合着する術式を基本とする CAMLOG インプラントを長期間の IMZ インプラントの結 果を基に 1998 年に新たに開発した（図 7).

\section{1 歯 1 本の考え方に基づくインプラント}

多数柬欠損において 1 本の柬に対して 1 本のインプラン トで修復する単独修復はオッセオインテグレーテッドイン 


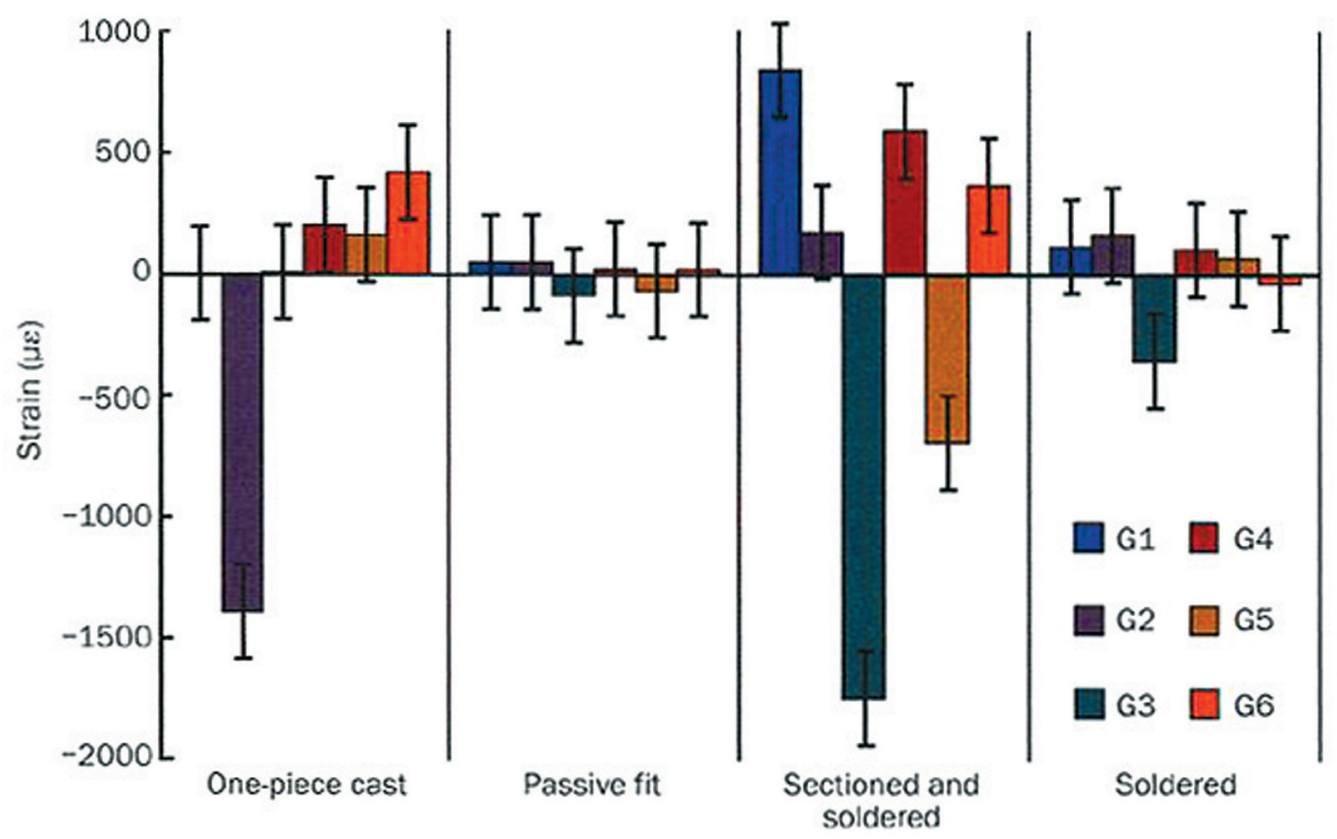

図 6 スクリュー固定式上部構造体製作法の違いによるスクリュー固定時の応力の発生
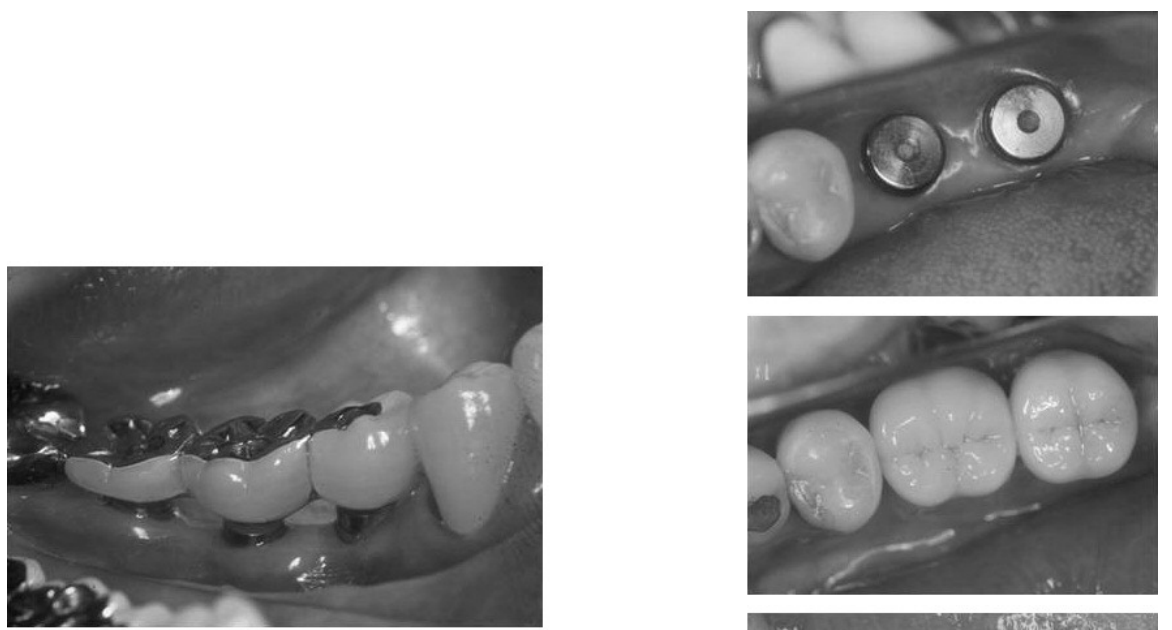

連結スクリュー固定の IMZ インプラント
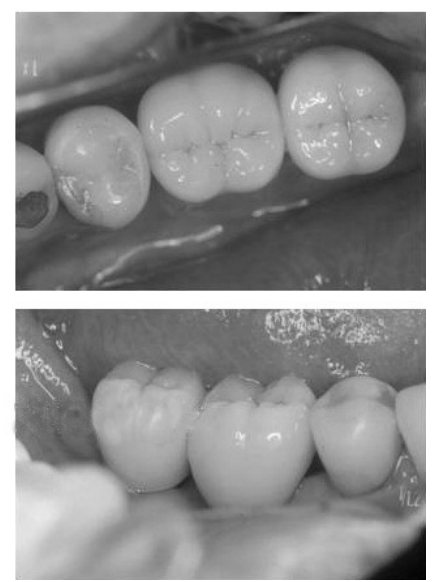

図 7 1㐘 1 本修復による考え方に基づく CAMLOG インプラント

プラント治療が臨床応用されてきた 40 年のなかで, 生ま れたものである.この修復を可能とするためにはシステム としてクリアーすべき点があった.これはインプラント体
と柬冠部支台となるアバットメントとの連結である. 従来 はブリッジ形式であり，インプラント体同士を連結したた め, 特に回転防止機構は必要ではなかった. しかし単独修 


Immediate Loading
Advantage
- psychological benefits
- reduces the patient's costs
- decreases the treatment time and
office visit
- few surgical exposures
- physiologic benefits
Disadvantage
- high risk of the non osseointegration
- difficulty of diagnosis and procedure
- difficulty of control the esthetic restoration

図 8 即時荷重の利点と欠点

復であるインプラントの場合は, インプラント体と㐘冠支 台部がリジッドに固定されなければならない. 現在全世界 で 200 数十種類のインプラントが市販されているがその連 結はさまざまである. 大別して内部連結機構, 外部連結機 構に分類されるが，そのデザインは個々のもので異なる. 連結部は緊密に適合することが重要であり, 非常に重要で ある。また上部構造製作にあたり，その位置を正確に再現 する印象システム, 上部構造作製システムの確立が重要で あった. CAMLOG インプラントは IMZ インプラントの 20 数年の臨床評価, 基礎研究を基に 1998 年に生み出された システムである. 我々も 2001 年より IMZ インプラントに 代わり CAMLOG インプラントの臨床応用を行ってきた. 現在まで 7 年が経過し, 1 柬欠損から無㐘顎までの適応で 347 人, 947 本の応用を行っている. その結果長期間の結果 ではないが 7 年での累積生存率は $98.9 \%$ あ゙あた ${ }^{7)}$.これ らの結果のなかでオッセオインテグレーションが 1 年以内 で得られなかったインプラント数は 9 本と多かった. これ は埋入時，骨移植，上顎洞底挙上術との処置を併用した症 例が多く，これらのリスクによるものと考えられる.今後 我々第 2 次医療機関はこのような比較的アドバンスな症例 が適用となることからもこれらの治療術式の確立が重要と なる。

\section{8.インプラント支台のオーバーデンチャー}

インプラントを支台としたオーバーデンチャーはリジッ ドな義茵を可能とすること, 可撤性であるため清掃が可能 であること, 修理が容易であることなどから臨床応用され てきた. 日本柬科大学新潟生命菌学部口腔インプラントセ ンターでも, IMZインプラント, CAMLOG インプラント による応用を行ってきた. 無㐘顎堤に 2 本から 6 本のイン プラントを埋入し，これにバーアタッチメントや ball \& socketアタッチメントを装着し, 義柬の固定とした。イン プラントは何れの場合も顎堤の左右対称に同数埋入し, 咬 合器上で顆頭点と平行な位置にマークし，ステントを用い てその位置を埋入した.オーバーデンチャーは周知のごと く，可撤性で有ることから患者にとって受け入れがたい部 分もあるが, 顔面全体で見た場合のリップサポートなどか らむしろ審美的利点が大きい場合もある．これらオーバー デンチャーの咬合力, 咀嚼効率の改善についてインプラン ト支台でない場合の義柬との違いについて報告し, インプ ラント支台のオーバーデンチャーの方が咀嚼効率は明らか に高いことを，また大きな咬合力があることを報告してい る $^{8)}$.

\section{9.イメディエートローディング}

イメディエートローディング（即時荷重）は多くの利点 があるものの, 欠点もある (図 8). 即時荷重の意味は上部 構造を介して即時にインプラント体に荷重付与することで あるが, 臨床の場では時折, これが的確用語として使用さ れていない. 即時荷重の定義は打そらく, 2002 年にスペイ ンのバルセロナで行われた ITI のコンセンサスミーテング 9) で行われたものと考える.これによるとイメディエートロ ーディングはインプラント埋入 48 時間以内に上部構造を 装着し, 対合㐘に接触荷重を付与することである. ちなみ にインプラント埋入 48 時間から 3 か月以内に荷重を負荷 する場合はアーリーローディング (早期荷重) とされてい る. 咬合の与え方としてはインプラントに暫間被覆冠を付 与し, 対合茵とは接触させないイメディエートテンポラリ 一ゼーション ウイズアウト コンタクト（暫間被覆間は 装着するけれども対合柬とは接触させない), 本来の上部 構造体を装着と同時に荷重を負荷するイメディエートロー ディング，そして最初に残存する天然㐘が接触し咬合する に従い徐々に接触するプローグレシブローディングであ る。これをまず明確化しなければならない. 現在まで即時 荷重, 早期荷重に関しての多くの論文, 報告がなされてい るが, 多くの研究は短期間のまた多施設での科学的な手法 による研究報告ではない.さらにオッセオインテグレーシ ヨンを得るための条件として揭げている Branemarkらの 定義を打ち消す論文が出されていない点でまだこれらの是 非について日常のルーティンな応用としては確立されてい ないと考える。下顎の無㐘顎においては Ladermann らの 長期に基づく報告 ${ }^{10 ）}$ がなされて打り，これは日常臨床で ルーティンな応用として認められる. 現在 CT のデータよ りガイドされた即時荷重の術式がシステマチックに行われ ているが，CTの画像が $100 \%$ 骨の状態を再現するもので ないこと, 埋入術式には誤差が伴うこと, 骨の性状は多種 多様であることなど大きなリスクを伴うもので有ることを 
再認識すべきである. 即時荷重は否定するわけではないが 十分に術前に多くのデータを集め，また手術は自分の目で， 手指の感覚で確かめながら行うことは必要であることは論 を持たない.

\section{結語}

インプラントを行う柬科医の数は現在, 10 人に一人とな ろうとしている.インプラント治療は欠損修復に対しての 重要な手段である.しかしインプラント治療には患者の全 身状態，局所状態の細部にわたる診査が重要であるととも に, これを行う㐘科医師の包括的な, 高度な治療技術が必 要となる. 具体的には適切な埋入手術の技術, 補経治療, 技工, 歯周はもちろんであるが, 生体解剖を知って治療に あたらなければならない. 今日多くの医療トラブルも報告 されている単にインプラントが骨とインテグレーションす ることがインプラント治療のゴールではない. インテグレ ーションしたインプラントを支台として審美, 機能回復し, 長期間の予後をもつことが求められている. このような点 からインプラント治療に対する, 知識の収集と, 治療技術 の向上が大切である.

\section{引用 文 献}

1) Branemark, P.I., Hansson, B.O., Adell, R., Breine, U., Lindström, J., Hallen, O. and Öhman, A.: Osseointegrated implants in the treatment of the edentulous jaw. Experience from a 10 year period. Scand J Plast Reconstr Surg Suppl. 16: 1-132 1977.
2) Garber, D.A. and Belser, U.C.: Restoration-driven implant placement with restoration-generated site development. Compend Contin Edue Dent 16: 7988021995.

3）竹下文隆，森永 太，松井孝道，阿部成善，添島義 和：インプラント治療に対する患者の意識調査. 日 口腔インプラント誌 19: 478-484 2006.

4) Balshi, T.J.: An analysis and management of fractured implants: A clinical report. Int J of Oral Maxillofac Implants 11: 660-666 1996.

5）渡邊文彦, 多和田泰之, 小松繁樹, 高瀬一郎, 畑 好 昭, 榎本紘昭, 古川達也, 榎本琴世：IMZ インプラ ントの生存率に関する 2 施設統合予後調査. 日蒾補 誌 46: 702-711 2002.

6) Watanabe, F., Uno, I., Hata, Y., Neuendorff, G., Kirsch, A.: Analysis of stress distribution in a screwretained implant prosthesis. Int J Oral Maxillofac implants 15: 209-218 2000.

7）渡邊文彦, 高瀬一郎, 小澤 誠, 多和田泰之, 上田一 彦，小林英三郎，又賀 泉，廣安一彦：CAMLOG インプラント 7 年間の評価 (抄). 日本柬科医師会 誌 61: 1262008.

8）金田 恒，高瀬一郎，小司利昭，廣安一彦，渡邊文 彦：インプラントオーバーデンチャーの臨床評価. 日口腔インプラント誌第 38 回学術大会抄録: 2008, 9.

9) Aparicio, C., Rangert, B., Sennerby, L.: Immediate/ early loading of dental implants: A report form the Sociedad Espanola de implnatss World Congress Consensus Meeting Barcelona, Spain, 2002. Clin Implant Dent Relat Res 5: 57-60 2003.

10) Ladermann, P.D.: Uber 20 jahrige erfahung mit der soforting funktionelln belastung von implantatstegen in der region interforaminalis. Z Zahnartl Implantol 12: 123-136 1996. 